\title{
FENNTARTHATÓSÁGRA NEVELÉS AZ ELTE TÓK TERMÉSZETTUDOMÁNYI TANSZÉKÉN
}

\section{Darvay Sarolta - Hill Katalin - Bauer Zita - Vitályos Gábor Áron}

Eötvös Loránd Tudományegyetem, Tanító- és Óvóképző Kar, Természettudományi Tanszék

\section{Bevezetés}

Az emberiség valódi globalizált világot teremtett magának. A fosszilis tüzelőanyagok felhasználása óta egyetlen faj, a Homo sapiens, mohó módon uralma alá vonta bolygónkat. Ma már antropocén korszakról beszélnek a szakemberek, utalva az 1950-es évek óta felgyorsult emberi tevékenységre a Földön (vö. Vida, 2012). Az ember egyoldalúan képes hasznot húzni a bioszféra müködéséböl.

Erkölcsi kérdés a környezeti vészhelyzet problémáinak megoldása. Emberjogi kérdés az igazságosság iránti kötelezettségünk. A tiszta, egészséges környezet megléte, morális kötelességünk. Hogyan jutunk el a morális kötelességtudattól a morális cselekvésig. Mi határozza meg erkölcsi értékeinket?

$\mathrm{Az}$ emberiség belátása bolygónkat fenyegető környezeti, társadalmi, gazdasági veszélyek iránt már nem lehet kérdéses. A felismerés, hogy az emberiség a kiegyensúlyozott földi világ rendszerének egy része, hogy létünk ennek a kiegyensúlyozott világ rugalmasságától, alakulásától függ, már evidencia. Ez határozza meg társadalmi, gazdasági létünket. Tehát világnézeti paradigmaváltásra van szükség. A fenntartható társadalom felé vezető út az antropocentrikus megközelítés helyett az ökocentrikus megközelítést követeli meg. Személyes ökológiai filozófiánk elveiből kell fakadjon viselkedésünk, elkötelezettségünk bolygónk iránt. Minden tettünk, hogy mit vásárolunk, mit eszünk, hogyan töltjük el szabadidőnket, ezekből az elvekből táplálkozik.

Egyéni életünk változása vezethet el a társadalmi változáshoz. Új értékrendünknek tükröződnie kell mindennapi tetteinkben. A környezettudatos és egészségtudatos magatartásunk pontos megnyilvánulása ennek a változásnak. Az egyéni tettek hosszútávon nem lesznek elegendőek azokhoz a változásokhoz, amikre a jövőben szükség lesz. Társadalmi összefogás szükséges, ehhez pedig olyan állampolgárokra, akik tanulmányaik során multidiszciplináris képzés kapcsán ismerik meg a fenntarthatóság elvét. Nem elegendő csupán környezettudományok, természettudományok oktatása a társadalom gondolkodásának átalakításához. A pedagógusképzésben olyan képzési struktúrára van szükség, ami a lényeglátást és az integrációt teszi lehetővé. 


\section{Az ELTE TÓK Természettudományi Tanszék képzési struktúrája, feladata}

A Természettudományi Tanszék a Kar mindkét alapszakán és tagozatán végzi a hallgatók természettudományos képzését. Ezen kívül részt vállal az ELTE Pedagógia és Pszichológiai Kar Neveléstudományi MA-képzés kora gyermekkor pedagógiája szakirányának képzésében, a Gyermek a természetben tantárgy oktatásával. Részt vesz szakirányú továbbképzési programok és modulok kidolgozásában, oktatásában.

Képzésünk során mind az elméletet, mind a gyakorlatot teljességgel átszövi a fenntarthatóság pedagógiája, jelen van minden oktatónk munkájában. Kiemelt fontosságú célunk, hogy olyan óvodapedagógusokat és tanítókat képezzünk, akik képesek akár az intézményen belüli, akár az azon kívüli színtereken a fenntarthatóság kultúrájának és a fenntartható életvitelnek az élményszerü, játékos alapozására és fejlesztésére. Ennek megvalósítása érdekében fontosnak tartjuk, hogy hallgatóinknak legyen alkalma megismerni a fenntarthatóságra nevelés elméletét és gyakorlatát, számos gyakorlati helyszínének szerepét, alkalmazott módszereit és eszközeit a fenntartható élethez elengedhetetlen holisztikus, illetve környezettudatos szemléletmód formálásában. A karon történő természetismereti képzés során ezért célunk, hogy hallgatóink felsőoktatási tanulmányaik során elsajátítsák a fenntarthatóságért felelős magatartás kialakításához szükséges legfontosabb ismereteket, hozzáállást és cselekvési kompetenciákat.

Tanító és óvópedagógus szakon egyaránt beépül a fenntarthatóság pedagógiájának szemlélete tanszékünk valamennyi természettudományos kurzusába, mind az elméleti ismeretekbe, mind a gyakorlatokba, mind pedig a terepi munkába.

2011 tavasza óta a tanító szakos, természetismeret müveltségterületes hallgatóink (akik 1-6. osztályban taníthatják a környezet-, majd a természetismeret tantárgyat) egy három féléven át tartó önkéntes szakmai gyakorlat segítségével ismerkedhetnek meg egy-egy, a fenntarthatóság szolgálatában álló intézménnyel, annak programjával, törekvéseivel. A hallgatók az alábbi, intézményünkön kívüli helyszínek közül választhatnak: ELTE Gyakorló Általános Iskola és Gimnázium, ahol két Európai Unió által támogatott nemzetközi projekt megvalósításába - BEAGLE és Carbondetectives projekt (Beagle projekt oldala, illetve Füzné, 2013, 2014, valamint Carbon Detectives projekt oldala és Carbon Detectives hivatalos oldala) - kapcsolódhatnak be, két Ökoiskola gyakorlati munkáját segíthették (Németvölgyi Általános Iskola, és 1. sz. Általános Iskola, Budaörs). Megismerhették a Magyar Természettudományi Múzeum, a Duna-Ipoly Nemzeti Park Sas-hegyi Természetvédelmi Területét és a Szemlö-hegyibarlangot, az ELTE TTK Ásványtani Tanszék fenntarthatóságra nevelés programját és a Pangea Egyesület müködését, valamint a Vakok Állami Intézetét.

Az óvópedagógus-képzésben a 2013. évtől kezdve külön specializációként is választhatják ezt a területet az ebben az irányban elkötelezett hallgatók. A specializáció során a tanegységeken keresztül a fenntarthatóságra nevelés elméleti 
kereteinek megismerése mellett kiemelt szerepet kap a fenntarthatóságra nevelés az óvodai gyakorlatban, az óvodán kívüli helyszíneken, bekapcsolódhatnak környezeti projektekbe, valamint külön kurzus segíti egészségfejlesztési ismereteik bővülését is.

Számos szabadon választott tanegység a képzés minden szakát érinti. Ilyenek például a következő kurzusok:

- Zoopedagógia (együttmüködve a Fővárosi Állat- és Növénykerttel),

- Fenntarthatóságra nevelés,

- Egészségfejlesztés,

- Globális gondok a 21. sz. elején,

- Környezetkultúra - környezettudatosság.

A gyakorlatban dolgozó szakemberek, óvodapedagógusok és tanítók ismereteinek és módszertani kultúrájának mélyítése és korszerüsítése érdekében szakirányú továbbképzéseket hirdetünk, melyek a következők:

- Élményt nyújtó környezeti fenntarthatóságra nevelés.

- Környezeti nevelő óvodapedagógus szak.

- Természetismeret müveltségterületi részismereti képzés.

2011 óta 29, az Erasmus hallgatói mobilitásban résztvevő külföldi hallgató végezte el sikeresen a tanszékünk által meghirdetett „Fenntarthatóságra nevelés” („Sustainability education”) címü kurzust. A hallgatók különböző országokból érkeznek, így: Bulgária, Észak-Írország, Hollandia, Németország, Olaszország, Spanyolország, és Törökország, ezért a kurzust angol nyelven tartjuk.

Célunk, hogy a különböző országokból érkezett Erasmusos hallgatók egymást és egymás országait, valamint ezen országok egyenkénti környezet- és természetvédelmi problémáit, és az ezek orvoslására, csökkentésére bevezetett, alkalmazott lehetőségeket megismerjék. A kurzus során a hallgatók megismerkednek Magyarország környezet- és természetvédelmi problémáival is, betekintést kapnak a környezeti nevelés iskolán kívüli helyszíneibe: ellátogatnak a budapesti Állat- és Növénykertbe, a Magyar Természettudományi Múzeumba, egy kiránduláson vesznek részt a Budai-hegységben, ahol az adott környezeti és természeti értékekkel ismerkednek meg.

Az elmúlt két évben az Erasmus oktatói mobilitás keretében Ausztriából, Németországból és Törökországból fogadott a tanszék vendégoktatókat. Az adott ország, illetve egyetem fenntarthatósággal kapcsolatos oktatási programjának bemutatása mellett (mely az egész kar érdeklődő oktatói és hallgatói számára nyitott), szoros együttmüködést próbálunk kiépíteni a hallgatók képzésében, közös terepgyakorlatok formájában.

A kötelezö stúdiumokon kívül közös tevékenységi formák kialakítására törekszünk a hallgatókkal, közös részvétellel nappali és levelező esti tagozatos hallgatók számára. Rendszeres szervezett programjaink a következők:

- szakmai látogatások helyszínei: Paksi Atomerőmü, Eötvös Múzeum és az Iskolatörténeti Kiállítás (Ercsi), Régészeti Park (Százhalombatta). 
ELTE TTK Ásványtani Tanszék - Történeti Ásványtár, ELTE TTK Biológiai és Öslénytani Gyüjtemény

- terepgyakorlatok az óvodapedagógus- és tanító-szakon rendszeresen ismétlődve a szorgalmi időszakban és azon kívül is. Az 5 napos komplex terepgyakorlat helyszínei: Mátranovák-Nyírmedpuszta, Répáshuta, Veröce-Csattogó völgy. Az egy napos terepgyakorlat helyszínei a Duna-Ipoly Nemzeti Park területén a Dinnyési fertő TT, Ipolytarnóci Ösmaradványok TT, Duna-Dráva Nemzeti Park területén a Gemenci-erdö,

- terepséták

○ helyszínek: Háros-szigeti Ártéri-erdő TT, Hunyadi-Háros sziget tanösvénye, Sas-hegy TT, Margitsziget, Mogyoróhegy, Normafa, Pál-völgyi-barlang, Szemlő-hegyi-barlang, Fővárosi Állat- és Növénykert, Gesztenyéskert, Mezőgazdasági Múzeum, Természettudományi Múzeum, Jókai kert TT,

- nyári táborok óvodapedagógus szakos hallgatókkal az ELTE TÓK Gyakorló Óvoda pedagógusaival és óvodásaival a Mátrában, Mátranovák-Nyírmedpuszta, Mátraszentistvánon,

- projekthét a Kari Napok rendezvénysorozatának szerves része. A fenntarthatóságra nevelés projekt nagy érdeklődésre tart számot, nagy létszámú hallgatói részvétellel, komoly szakmai és módszertani eredménnyel.

A kiemelkedő képességű vagy érdeklődésű hallgatók bekapcsolnak a tanszék tudományos munkájába. A tanszéken két tudományos diákköri mühely alakult ki, az egyik a „Környezeti nevelés, fenntarthatóságra nevelés”, a másik az „Egészségfejlesztés”. Ezeken belül különböző témákban dolgoznak együtt oktatók és hallgatók, hangsúlyozottan tantárgy-pedagógiai megközelítéssel. Kari és országos diákköri konferenciákon szép eredménnyel szerepelnek hallgatóink.

A kiemelkedő képességü hallgatók közül kerülnek ki többnyire a tanszék tudományos ösztöndijat elnyert hallgatói. Ök segítenek a lemaradt hallgatók felzárkóztatásában, a tanszéki rendezvények szakmai kidolgozásában, szervezésében, lebonyolításában, pl: Föld napi vetélkedő, Egészségnap; a kiemelt környezeti ünnepek alkalmából rendezett figyelemfelhívó kiállítások.

A hallgatók egyéni érdeklődésének kielégítését szolgálják a kiemelt, aktuális témaköröket érintő fent említett szabadon választható tárgyak köre.

Programjaink megvalósításában támaszkodunk egyes szakmai intézmények, civil szervezetek, hazai és külföldi társintézmények együttmüködésére.

$\mathrm{Az}$ oktatási tevékenység minőségének alapját az oktatók szakmai felkészültsége és ennek állandó fejlesztése, az oktatók megújulásra való készsége és hajlandósága, innovatív szemlélete biztosítja

Oktatóink szakmai fejlődésének fontos eleme, hogy bekacsolódnak az Erasmus oktatói mobilitás programba. Ennek keretében az elmúlt években 
lehetőség nyílt betekinteni a Babeş-Bolyai Tudományegyetem, a Barcelonai Egyetem, a Evangelische Hochschule Freiburg, Pädagogische Hochschule Schwäbisch Gmünd, a Marnix Academia Utrecht oktatói munkájába.

2014-ben kezdeményeztük a fenntarthatóságra nevelés témában, (környezeti nevelés, egészségnevelés, egészségfejlesztés) a közép-európai tanító- és óvóképző társintézmények együttműködését. Ennek keretét a 2014/2015-ös tanévre a CEEPUS (Central European Exchange Program for University Studies) pályázatunk segítségével kívánjuk megvalósítani. A hálózati együttmüködés témája: Effective Approach to Sustainability Education. A hálózat résztvevői a Babeş-Bolyai Tudományegyetem, Pszichológia és Neveléstudományok Kar, Pedagógia és Alkalmazott Didaktika Intézet, Kolozsvár, az Újvidéki Egyetem Magyar Tannyelvü Tanítóképző Kara, a Selye János Egyetem Komárnóban és a Nyitrai Konstantin Filozófus Egyetem Közép-Európai Tudományok Kara.

A Kar hallgatói elsősorban nem természettudományos érdeklődésűek, a hátránykompenzáció szempontjából nagy teher hárul a tanszéki oktatókra. A hátrányok kompenzációját egyéni és csoportos konzultációval igyekszik segíteni a tanszékünk. Célunk a természettudományos ismereteinek bővítésén túl a hallgatók környezettudatos kompetenciájának, módszertani kultúrájának bővítése.

\section{Irodalom}

Beagle projekt oldala http://mkne.hu/projektek.php?projekt=10

Carbon Detectives hivatalos oldala www.carbondetectives.hu

Carbon Detectives projekt oldala http://mkne.hu/projektek.php?projekt=12

Füzné Koszó Mária (2012): A BEAGLE Program. Fákat vallató fiatalok. Természetbúvár 65., 40-41.

Füzné Koszó Mária (2013): Out of Classroom Project for Biodiversity education in Hungary: A Case Study. US-China Education Review B, 3. 11., 870-881.

Vida Gábor (2012): Honnan hová, Homo? Az antropocén korszak gondjai. Semmelweis Kiadó, Budapest. 